\title{
Chemical Composition and Enzymes Inhibitory, Brine Shrimp Larvae Toxicity, Antimicrobial and Antioxidant Activities of Caloplaca
} biatorina

\author{
Tahereh Valadbeigi ${ }^{1}$ \\ ${ }^{1}$ Department of Biology, Faculty of Sciences, Ilam University, Ilam, IR Iran \\ "Corresponding author: Tahereh Valadbeigi, Department of Biology, Faculty of Sciences, Ilam University, Ilam, IR Iran. Tel: +98-9126092197, Fax: +98-32227022, E-mail: \\ tvaladbeigi@yahoo.com
}

Received 2015 October 07; Revised 2015 October 31; Accepted 2016 October 28

\begin{abstract}
Background: This study evaluated the brine shrimp larvae toxicity and enzymes inhibitory especially anti-diabetic potential of Caloplaca biatorina via in vitro inhibition of $\alpha$-amylase and $\alpha$-glucosidase using the methanol extracts. Also aldehyde oxidase and xanthine oxidase enzymes inhibitory, cytotoxicity, and antioxidant activities of the species were determined.

Methods: In this experimental study, different concentrations of the extracts $(0.2,5.0,1$ and $1.5 \mathrm{mg} / \mathrm{mL})$ were incubated with enzyme substrate solution and the percentage of enzyme inhibitory activity and $\mathrm{IC}_{50}$ was calculated. Folin-Ciocalteu reagent and aluminium chloride colorimetric methods were used to estimate total phenolic and flavonoid content of extracts. The toxicity of the extract was assessed using the brine shrimp lethality bioassay. The minimal inhibitory concentration (MIC) and minimum bactericidal concentration (MBC) were determined. High-performance liquid chromatography and Thin-layer chromatography analysis were evaluated. The data were analyzed by SPSS V.21 software.

Results: Parietin, Emodin, 1,8-Dihydroxy-3-(hydroxymethyl)-6- methoxy-9.10-anthracenedione and Rhein were identified. The extract showed strong $\alpha$-glucosidase, aldehyde oxidase and xanthine oxidase inhibitory activities with $\mathrm{IC}_{50}$ value of 17.12, 40.09 and $11.02 \mu \mathrm{g} / \mathrm{mL}$ respectively. Also methanol extract displayed the strongest DPPH radical scavenging and brine shrimp toxicity $\left(\right.$ IC $_{50}=$ 91.11) properties.

Conclusions: The result obtained suggests that the $C$. biatorina extract can be classified as non-toxic. Also, it revealed the antioxidant and antidiabetic potential of the lichen.
\end{abstract}

Keywords: Alpha-Amylase, Alpha-Glucosidase, Diabetes Mellitus, Hyperglycemia

\section{Background}

Diabetes mellitus (DM) is a chronic progressive metabolic disorder. It characterized by high blood glucose levels. It is estimated that $25 \%$ of the world population is affected by this disease. One therapeutic approach to treat diabetes is to retard the absorption of glucose through inhibition of enzymes, like $\alpha$-glucosidase and $\alpha$-amylase, in the digestive organs. Several $\alpha$-glucosidase inhibitors have been isolated from medicinal plants like Cinnamomum zeylanicum [1], Salvia spinosa, Polygonum hyrcanicum [2] and Orthosiphon stamineus [3]. Also screening tests with lichens have demonstrated the frequent occurrence of metabolites with antibiotic, antimycobacterial, antiviral, anti-infammatory, analgesic, antiproliferative, antipyretic, and cytotoxic properties [4]. These medicinal compounds develop as an alternative drug with increased potency and lesser adverse effects than the existing drugs [5].
Aldehyde oxidase (AO) enzyme is involved in oxidative stress and oxidising of several important drugs like mercaptopurine, methotrexate, famciclovir, 6- azathioprine, quinine and quinidine. It is a cytosolic enzyme and belongs to the molybdenum hydroxylase family. It seems to be involved in hormone biosynthesis such as those of indole- 3-acetic acid and abscisic acid. AO with xanthine dehydrogenase/xanthine oxidase (XD/XO), collectively known as xanthine oxidoreductase (XOR) [6, 7].

Despite a large number of natural antioxidant products, the investigation for new chemical entities with antioxidant activity still remains a burgeoning field. For this reason, lichens are an important source for new antioxidant agents. I hypothesized that antioxidant activity of lichens may decrease hyperglycaemia-induced oxidative stress and prevent the development of diabetic Caloplaca biatorina (A. Massal.) J. Steiner was investigated for the first time in the present study. 
Lichen is a composite organism that arises from green algae or cyanobacteria or both. The fungal partners are mostly (98\%) Ascomycota and the others belong to the Basidiomycota. Approximately 18,000 species of lichen have been described and identified worldwide. They are one of the slowest growing symbiotic associations. They have a variety of different growth forms as (1): Crustose, (2): Foliose and (3): Fruticose. They have an interesting chemistry and produce a large number of specific acids. For example, usnic acid which is a very active substance is used in pharmaceutical preparations. This acid is a cell division regulator of autotrophic partner of lichen symbiosis-photobiont. Generally, lichens produce two different types of metabolites; primary and secondary. Secondary metabolites are produced by the fungal partner. These compounds are mainly depsides, depsidones, dibenzo-furans, xanthones and terpene derivatives. These unique metabolites sometimes make more than $30 \%$ of the dry mass of thallus. Some of these compounds are utilized in drugs that can be more effective than antibiotics such as penicillin. These secondary metabolites have shown a wide range of biological properties including antibiotic, antimycobacterial, antiviral, anti-protozoan, anti-inflammatory, analgesic, antipyretic, antiproliferative, cytotoxic effects and antioxidant activities [4-8].

\section{Methods}

All media and materials used in this experimental study were obtained from (Merck Co. Darmstadt, Germany). Antibiotics were obtained from (Mast Group Ltd., UK). The strains were obtained from Persian type culture collection (PTCC, Tehran, Iran) or American type culture collection (ATCC, Manassas, VA).

\subsection{Lichen Material}

The specimens of C. biatorina were collected in April 2006 from Mehran, Ilam province of Iran. The lichen was identified by Prof. Harrie Sipman, Curator of Lichens at the Botanischer Garten and Botanisches Museum BerlinDahlem and a voucher specimen was deposited for the lichen (B-6346).

\subsection{Preparation of the Lichen Extracts}

Dry ground thalli of the investigated lichens (10 g) were extracted using methanol $(250 \mathrm{~mL})$ in a Soxhlet extractor (model 6718, Ace Glass Inc., Vineland, NJ.). The extracts were filtered and then concentrated under reduced pressure in a rotary evaporator (Model RE 200). Resulted extracts were stored at $-18^{\circ} \mathrm{C}$ in dark until analysis. The extracts were dissolved in 5\% dimethylsulfoxide (DMSO) for the experiments [8].
2.3. Thin Layer Chromatography (TLC) and High-Performance Liquid Chromatography (HPLC)

Compounds were characterized by the standardized TLC method [9-11] and gradient-elution high performance liquid chromatography (HPLC) [12].

\subsection{Total Phenolic Content (TPC)}

TPC of the extract was determined by the method of Folin-Ciocalteu according to a reported procedure [13].

\subsection{Total Flavonoid Content (TFC)}

TFC of the extracts was determined using the aluminium chloride colorimetric [14].

\subsection{DPPH Radical Scavenging Activity}

The DPPH radical scavenging capacity of the extract was evaluated using a previously published method $[15,16]$.

\subsection{Ferric Reducing Power}

The procedure was applied by the method of Zhao et al. [17].

\section{8. $\alpha$-Glucosidase Inhibitory Activity (AGI)}

AGI of $C$. biatorina was evaluated according a previously described method [18].

\section{9. $\alpha$-Amylase Inhibitory Activity (AAI)}

$\alpha$-amylase (AA) inhibition assay was used according to Giancarlo et al. [19].

\subsection{Aldehyde Oxidase Inhibitory Activity (AOIA)}

AOI of the extract was evaluated using a previously published method [20].

\subsection{Xanthine Oxidase Inhibitory Activity (XOIA)}

XOIAs of the lichen samples were measured spectrophotometrically [20]. Prior to any assay, the substrate and the enzyme solutions were prepared. The reaction mixture contained an $80 \mathrm{mM}$ sodium pyrophosphate buffer ( $\mathrm{pH}=8.5), 0.120 \mathrm{mM}$ xanthine, and 0.1 unit of XO. XO activity was determined by measurement of uric acid production at $295 \mathrm{~nm}$ The methanolic dried extract, initially dissolved and diluted in the buffer, was incorporated in the enzyme assay to assess its inhibitory activity at a final concentration of $200 \mu \mathrm{g} / \mathrm{mL}$. Results were expressed as average values of three independent assays. A negative control (blank; 0\% XO inhibition activity) was prepared containing the assay mixture without the extract. Quercetin was used as a positive control in the assay mixture. The reaction was monitored in the presence of lichen samples $(10-500 \mu \mathrm{g})$ and the results were compared with the inhibitory effect of positive control $(0.5-5 \mu \mathrm{g})$. All the experiments were performed using a Shimadzu spectrophotometer (2550 UV/VIS). 


\subsection{Determination of Antibacterial Activity}

Three-positive bacteria [Bacillus cereus (PTCC 1015), $B$. subtilis (ATCC 1399) and Staphylococcus aureus (ATCC 25213)], three Gram-negative bacteria [Pseudomonas aeruginosa (ATCC 1047), Escherichia coli (PTCC 2405) and Salmonella typhi PTCC 1609] and two fungi [Aspergillus niger (PTCC 5012) and Candida albicans (PTCC 5027) were used as test organisms. All the used microbial strains were obtained from the Pasteur institute of Iran. The minimal inhibitory concentration (MIC) and minimum bactericidal concentration $(\mathrm{MBC})$ were determined by the broth microdilution method with using 96-well micro-titer plates as described previously [21]. A series of dilutions with concentrations ranging from 63 to $1000 \mathrm{mg} \mathrm{mL}^{-1}$ for extracts were used in the experiment against every microorganism tested. Gentamicin and nystatin were used as positive control in antibacterial and antifungal assays, respectively. A DMSO solution was used as a negative control for the solvents influence. All assays were done in triplicate.

\subsection{Brine Shrimp Lethality Assay (BSLA)}

Brine shrimp lethality test was used to evaluate the toxicity of lichen's extracts. Brine shrimp larvae toxicity assays were performed according to the method published previously [22]. The eggs of Artemia salina were hatched in a flask containing artificial seawater (3.6\% w/v salt) for 48 hours, at room temperature. The test samples were dissolved in DMSO. Ten larvae were collected and added to the two fold serially diluted solutions with concentration range of $31-1000 \mu \mathrm{g} / \mathrm{mL}$ in the test tubes with the help of a pasteur pipette. The vials were kept for 24 hours. Larvae were considered dead if they did not exhibit any internal or external movement during the several seconds of observation. After 48 hours, a magnifying glass was used to count the number of dead and surviving larvae and the mortality percentage was calculated. DMSO and potassium dichromate were taken as negative and positive controls respectively. $\mathrm{LC}_{50}$ values were expressed as mean of triplicates \pm SEM.

\subsection{Statistical Analysis}

All the results were expressed as mean \pm SEM for three experiments in each. All the grouped data were analyzed by SPSS V.21 software. Statistical comparisons were estimated by one-way ANOVA followed by Duncan's post-hoc test for multiple comparisons with control. P value $<0.05$ was considered as statistically significant. Pearson's bivariate correlation test was carried out to calculate correlation coefficients ( $r$ ) between the content of total phenolic and the DPPH radical scavenging activity.

\section{Results}

\subsection{HPLC and TLC Studies}

Five chemical substance as (1): Parietin, (2): $1 \mathrm{H}$ Isoindole-1, 3 (2H)-dione, 2-buty l-4, 5, 6, 7-tetrahydro-, (3): Emodin, (4): 1,8-Dihydroxy-3-(hydroxymethyl)-6- methoxy9.10-anthracenedione, and (5): Rhein were detected as the major compounds of the extract. These compounds are reported for the first time from this lichen.

\subsection{Total Phenol and Flavonoid Contents}

The amount of total phenolic compounds was determined as the pyrocatechol equivalent using an equation obtained from a standard pyrocatechol graph $(\mathrm{y}=0.0021 \mathrm{x}$ - 0.0092, $\left.\mathrm{R}^{2}=0.9934\right)$. So that high absorbance was indicated high reducing power. Measured values of absorbance varied from 0.5 (concentration $0.2 \mathrm{mg} \mathrm{mL}^{-1}$ ) to 1.98 (concentration $1.5 \mathrm{mg} \mathrm{mL}^{-1}$ ). As shown in Table 1, excellent flavonoid content was found in extracts of $C$. biatorina $\left(128.17 \mu \mathrm{g}\right.$ of rutin equivalent in $1.5 \mathrm{mg} \mathrm{mL}^{-1}$ concentration). This tested extract exhibited high radical scavenging activity and ferric reducing power with the great amount of phenolic content. High phenolic content was identified in methanol extract of the lichen $(189.98 \mu \mathrm{g}$ of pyrocatechol equivalent in $\mathrm{mg} \mathrm{mL}^{-1}$ concentration). Correlation coefficient between the phenolic compound content of the tested extracts and free radical scavenging activity was $\mathrm{r}=$ 0.949 .

\subsection{Antioxidant Activity}

\subsubsection{Radical Scavenging Activity and Ferric Reducing Power} (SRP)

The antioxidant activity of the extract of C. biatorina was demonstrated by DPPH and FRAPS assays (Table 1). The extract showed the high DPPH radical scavenging activity with an $\mathrm{IC}_{50}$ value of $110.57 \mu \mathrm{g} / \mathrm{mL}$ (in $1.5 \mathrm{mg} \mathrm{mL}^{-1}$ concentration). Total phenolic and flavonoid contents of the extracts studied in the present work have good correlation with their DPPH radical scavenging activities $\left(\mathrm{r}^{2}=0.953, \mathrm{P}\right.$ $<0.05$, and $\mathrm{r}^{2}=0.961, \mathrm{P}<0.05$, respectively). In this research, the FRAP (ferric reducing antioxidant power) assay was used to evaluate the reducing potential of C. biatorina. SRP was calculated for tested sample (Table 1).

\subsection{Enzyme Inhibitory Activity}

\subsection{1. $\alpha$-Glucosidase Inhibition}

The results showed that extract of the lichen has high $\alpha$-glucosidase inhibitory activity $(17.12 \mu \mathrm{g} / \mathrm{mL}$ in $1.5 \mathrm{mg}$ $\mathrm{mL}^{-1}$ concentration) which is comparable with standard inhibitor acarbose $(16.9 \mu \mathrm{g} / \mathrm{mL})$ (Table 2$)$. There is a very good accordance between phenolic and flavonoid contents with 
Table 1. Total Phenol and Flavonoid Content and DPPH Assay, and Slop of Trend Line in Reducing Power Assay (SRP) of Caloplaca biatorina ${ }^{\mathrm{a}}$

\begin{tabular}{|c|c|c|c|c|c|}
\hline Concentration, $\mathrm{mg} / \mathrm{mL}$ & 0.2 & 0.5 & $\mathbf{1}$ & 1.5 & P Value \\
\hline Flavonoid, TFC; mg QEs/g dry wt. & $45.12 \pm 0.01$ & $52.18 \pm 0.01$ & $108.12 \pm 0.03$ & $128.17 \pm 0.02$ & 0.001 \\
\hline Phenol, TPC; mg GAEs/g dry wt. & $86.98 \pm 0.02$ & $105.32 \pm 0.01$ & $148.45 \pm 0.05$ & $189.98 \pm 0.02$ & 0.001 \\
\hline DPPH, IC $_{50} \mu \mathrm{g} / \mathrm{mL}$ & $34.02 \pm 0.01$ & $48.12 \pm 0.03$ & $98.54 \pm 0.02$ & $110.57 \pm 0.01$ & 0.001 \\
\hline SRP & $0.49 \pm 0.01$ & $0.58 \pm 0.01$ & $0.87 \pm 0.01$ & $1.09 \pm 0.01$ & 0.001 \\
\hline
\end{tabular}

${ }^{\mathrm{a}}$ Values are expressed as mean $\pm \mathrm{SD}$

$\alpha$-glucosidase inhibitory activity of the extracts of $C$. biatorina $\left(\mathrm{r}^{2}=0.911, \mathrm{P}<0.05\right.$, and $\mathrm{r}^{2}=0.947, \mathrm{P}<0.05$, respectively) that demonstrates these metabolites could be responsible compounds for the observed inhibitory activities.

\subsection{2. $\alpha$-Amylase Inhibition}

In the present study, the inhibitory activity of C. biatorina on $\alpha$-amylase was weak and it did not reach the 50\% inhibition level of enzyme activity (Table 2).

\subsubsection{Aldehyde Oxidase Inhibition (AOI)}

The extract in $1.5 \mathrm{mg} \mathrm{mL}^{-1}$ concentration showed a significant $\mathrm{AOI}\left(\mathrm{IC}_{50}=40.09 \mu \mathrm{g} / \mathrm{mL}\right)$ and was found to be a stronger inhibitor $\left(\mathrm{IC}_{50}=400.98 \mu \mathrm{g} / \mathrm{mL}\right.$ ) (Table 2 ). The extract of $C$. biatorina displayed a concentration-dependent AOI inhibitory activity.

\subsubsection{Xanthine Oxidase Inhibition (XOI)}

In this study, the lichen extract in $1.5 \mathrm{mg} \mathrm{mL}^{-1}$ concentration showed significant xanthine oxidase inhibitory activity $\left(\mathrm{IC}_{50}=11.02 \mu \mathrm{g} / \mathrm{mL}\right.$ ) (Table 2 ).

\subsection{Antimicrobial Activity}

The result of screening the lichen extract for antimicrobial activity is summarized in Table 3. It was found that the inhibition zone of tested bacteria against extracts have changed between 7-31.2 mm. Among all the tested bacteria minimum activity was observed against Staphylococcus aureus $(14 \mathrm{~mm}, \mathrm{MIC}=500, \mathrm{MBC}=500)$ and maximum activity was demonstrated against Bacillus cereu $(33.2 \mathrm{~mm}$, MIC $=125, \mathrm{MBC}=250$ ) in 1.5 concentration of the extract. The result showed that standard antibiotics significantly had less activity than the lichen extract (Table 3).

\subsection{Brine Shrimp Larvae Toxicity}

The $\mathrm{LC}_{50}$ value for the percentage of mortality brine shrimp treated with C. biatorina extract as indicated by the regression equation $\left(R^{2}=0.8520\right)$ was found to be 9001.11 $\mu \mathrm{g} / \mathrm{mL}$ (in $1.5 \mathrm{mg} \mathrm{mL}^{-1}$ concentration). The value was significantly $(\mathrm{P}<0.05)$ higher when compared to the standard potassium dichromate $\left(\mathrm{LC}_{50}=163.09 \mu \mathrm{g} / \mathrm{mL}\right.$ ) (Table 4$)$. In addition there was also a significant correlation $(\mathrm{P}<0.05)$ between the concentration of the extracts and the percentage of mortality value, it was found to be increased with increase in the concentration for the lichen tested and the standard.

\section{Discussion}

In summary the present results showed that the extract with the DPPH radical scavenging and brine shrimp toxicity $\left(\mathrm{IC}_{50}=91.11 \mu \mathrm{g} / \mathrm{mL}\right)$ activities, has a strong $\alpha$-glucosidase $\left(\mathrm{IC}_{50}=17.12 \mu \mathrm{g} / \mathrm{mL}\right.$ ), aldehyde oxidase $\left(\mathrm{IC}_{50}=40.09 \mu \mathrm{g} / \mathrm{mL}\right)$ and xanthine oxidase $\left(\mathrm{IC}_{50}=\right.$ $11.02 \mu \mathrm{g} / \mathrm{mL}$ ) inhibitory properties. Also phytochemical screening of the extract shows the presence of parietin, emodin, 1,8-dihydroxy-3-(hydroxymethyl)-6- methoxy-9.10anthracenedione and rhein.

Lichens are valuable natural resources and are used as remedies in folk medicines. These medicines are getting more importance in the treatment of diabetes as they are free from side effects and less expensive when compared to synthetic hypoglycemic agents. Prior to the patent of novel $\alpha$-glucosidase inhibitors from lichens by Thadani et al. there were no reports on the anti-hyperglycemic effects of the lichen metabolites [23]. Up till now, about 18 metabolites such as 3- $\beta$-acetoxyurs-11-en-13 $\beta$, 28-olide, 3-OAcetyl-betulinic acid, Betulinic acid and Ursolic acid (from Rhododendron), 1 - 5, triterpenoid zeorin (from Cladonia) and salazinic acid, sekikaic acid and usnic acid (from $R a$ malina) have shown potent $\alpha$-glucosidase inhibitory activity $[4,24,25]$. Also in some research, anthraquinones have been shown to be responsible for the strong $\alpha$ glucosidase inhibitory activities $[26,27]$. So, in this study the high inhibition of glucosidase by the lichen $C$. biatorina could be mainly due to the presence of phenolic constituents like anthraquinones compounds (e. g. parietin, emodin,1,8-Dihydroxy-3-(hydroxymethyl)-6- methoxy-9.10anthracenedione, and rhein) and other secondary metabo- 
Table 2. $\alpha$-Glucosidase, $\alpha$-Amylase, Aldehyde Oxidase and Xanthine Oxidase Inhibitory Activity of the Extract of Caloplaca biatorina ${ }^{\mathrm{a}, \mathrm{b}}$

\begin{tabular}{|c|c|c|c|c|c|c|}
\hline Concentration, $\mathbf{m g} / \mathbf{m L}$ & 0.2 & 0.5 & $\mathbf{1}$ & 1.5 & PValue & Quercetin \\
\hline$\alpha$-Glucosidase, AGI; $\mathbf{I C}_{50} \mu \mathrm{g} / \mathbf{m L}$ & $100.17 \pm 0.02$ & $83.12 \pm 0.03$ & $41.18 \pm 0.01$ & $17.12 \pm 0.01$ & 0.001 & $16.9 \pm 0.02$ \\
\hline$\alpha$-Amylase, $\mathbf{A A} ; \mathbf{I C}_{50} \mu \mathrm{g} / \mathrm{mL}$ & $340.67 \pm 0.81$ & $318.12 \pm 0.67$ & $314.01 \pm 0.70$ & $308.02 \pm 0.90$ & 0.001 & $10.05 \pm 0.80$ \\
\hline Aldehyde oxidase, AOI; IC $50, \mu \mathrm{g} / \mathrm{mL}$ & $400.98 \pm 0.02$ & $169.45 \pm 0.05$ & $111.32 \pm 0.01$ & $40.09 \pm 0.02$ & 0.001 & $1.26 \pm 0.03$ \\
\hline Xanthine oxidase, XOI; IC fo $\mu \mathrm{g} / \mathrm{mL}$ & $186.78 \pm 0.01$ & $89.98 \pm 0.02$ & $32.87 \pm 0.03$ & $11.02 \pm 0.03$ & 0.001 & $1.17 \pm 0.09$ \\
\hline $\begin{array}{l}\text { a Values are expressed as mean } \pm \text { SD. } \\
{ }^{b} \text { Standard. }\end{array}$ & & & & & & \\
\hline
\end{tabular}

Table 3. Antimicrobial Activity of the Methanol Extract of Caloplaca biatorina ${ }^{\mathrm{a}, \mathrm{b}}$

\begin{tabular}{|c|c|c|c|c|c|c|c|c|c|}
\hline & \multicolumn{9}{|c|}{ Mean (Average) Inhibition Zone, $\mathrm{mm}^{\mathrm{c}}$} \\
\hline & \multicolumn{5}{|c|}{ Bacteria } & \multicolumn{4}{|c|}{ Fungi } \\
\hline & Bacillus cereus & Bacillus subtilis & $\begin{array}{l}\text { Staphylococcus } \\
\text { aureus }\end{array}$ & Escherichia coli & Salmonella typhi & Aspergillus niger & Candida albicans & Dreschlera turcica & $\begin{array}{c}\begin{array}{c}\text { Fusarium } \\
\text { verticillioides }\end{array} \\
\text { veride }\end{array}$ \\
\hline $0.2^{d}$ & $10 \pm 0.15$ & $8 \pm 0.61$ & $7 \pm 0.4$ & $9 \pm 0.5$ & $7 \pm 0.4$ & $11 \pm 0.1$ & $6 \pm 0$ & $9 \pm 0.34$ & $7 \pm 0.45$ \\
\hline 0.5 & $15 \pm 0.30$ & $10 \pm 0.02$ & $9 \pm 0.21$ & $12 \pm 0.21$ & $9.01 \pm 0.4$ & $14 \pm 0.21$ & $6 \pm 0$ & $14 \pm 0.16$ & $12 \pm 0.31$ \\
\hline 1 & $21 \pm 0.01$ & $16 \pm 0.12$ & $11 \pm 0.49$ & $13 \pm 0.19$ & $14.1 \pm 0.4$ & $18 \pm 0.51$ & $6 \pm 0$ & $18 \pm 0.18$ & $16 \pm 0.80$ \\
\hline 1.5 & $31.2 \pm 0.22$ & $28 \pm 0.01$ & $14 \pm 0.9$ & $17 \pm 0.43$ & $16.9 \pm 0.4$ & $23 \pm 0.18$ & $6 \pm 0$ & $23 \pm 0.09$ & $19 \pm 0.01$ \\
\hline Standard $^{\mathrm{e}}$ & Gentamicin & Streptomycin & Clindamycin & Gentamicin & Streptomycin & $f$ & - & - & - \\
\hline Clindamycin & $25.33 \pm 0.57$ & $25.00 \pm 00$ & $9.66 \pm 0.12$ & $19.66 \pm 0.43$ & $8.66 \pm 15$ & . & - & . & - \\
\hline DMSo & $6 \pm 0$ & $6 \pm 0$ & $6 \pm 0$ & $6 \pm 0$ & $6 \pm 0$ & - & $\cdot$ & - & $\cdot$ \\
\hline Nystatin & - & - & - & - & - & $15 \pm 0.12$ & $15.5 \pm 0.26$ & $22 \pm 0.57$ & $16 \pm 0.33$ \\
\hline DMSO & $6 \pm 0$ & $6 \pm 0$ & $6 \pm 0$ & $6 \pm 0$ & $6 \pm 0$ & & & & \\
\hline P Value & 0.001 & 0.001 & 0.001 & 0.001 & 0.001 & 0.001 & 0.001 & 0.001 & 0.001 \\
\hline $\begin{array}{l}\mathrm{a}_{\text {Tested at a con }} \\
\mathrm{b}_{\text {Tested at a con }} \\
{ }_{\text {C Includes diam }} \\
{ }^{{ }^{d}} \text { Concentration } \\
e_{\text {Tested at a con }} \\
{ }^{{ }_{\text {N }} \text { inhibition }}\end{array}$ & $\begin{array}{l}\text { ntration of } 35 \mathrm{~mL} / \mathrm{d} \\
\text { ntration of } 15 \mathrm{~mL} / \mathrm{d} d \\
\text { er of disc }(6 \mathrm{~mm}) \text {. } \\
\text { f the extract. } \\
\text { ntration of } 10 \mathrm{~mL} / \mathrm{d} \\
\text { tected. }\end{array}$ & & & & & & & & \\
\hline
\end{tabular}

Table 4. Brine Shrimp Toxicity of the Extract of Caloplaca biatorina

\begin{tabular}{|c|c|c|c|c|c|c|}
\hline Concentration of the extract, $\mathrm{mg} / \mathrm{mL}$ & 0.2 & 0.5 & $\mathbf{1}$ & 1.5 & Potassium Dichromate $^{a}$ & PValue \\
\hline brine shrimp toxicity BSLA; $\mathbf{L C}_{50} \mu \mathrm{g} / \mathrm{mL}$ & $5008.02 \pm 0.02$ & $6001.12 \pm 0.02$ & $7009.91 \pm 0.02$ & $9001.11 \pm 0.09$ & $163.09 \pm 4$ & 0.001 \\
\hline
\end{tabular}

${ }^{\mathrm{a}}$ Standard.

lites (e. g., 2-buty l-4,5,6,7-tetrahydro-1H-Isoindole-1,3(2H)dione). However they could not be tested because of the scarcity of the samples. Therefore, the lichen could be subjected to extensive bio-assay guided chromatographic separation and purification processes for isolation of active molecules for the discovery of novel therapeutic agents. Also the mechanism by which C. biatorina exerted action may be due to its action on carbohydrate binding regions of $\alpha$-glucosidase enzyme, $\alpha$-amylase, endoglucanases that catalyse hydrolysis of the internal $\alpha-1,4$ glucosidic linkages in starch and other related polysaccharides have also been targets for the suppression of postprandial hyperglycemia. The mechanism should be verified by further studies.
To date lichens as Ramalina, Parmotrema, Usnea, Everniastrum and Pseudotinctorum caused higher inhibition of enzyme activity in diabetes mellitus [28]. To the best of my knowledge there is no previous report on antidiabetic properties of Caloplaca and this is the first report that showed higher $\alpha$-glucosidase inhibitory activity for C. biatorina than potassium dichromate as standard. So it is initial steps in new antidiabetic drug discovery, but further studies are necessary to verify the safety and efficacy of this therapy.

AO (Aldehyde oxidase) is a protein belonging to the family of molybdo- and tungsten-enzymes. This enzyme is involved several important drugs like methotrexate, fam- 
ciclovir, quinine and azathioprine [2]. To the best of my knowledge this study is the first research on the AOI activity of lichens and previous reports on the xanthine oxidase inhibitor activity hadn't been done. In this study $C$. biatorina had the best aldehyde oxidase inhibitory activity at concentration $1.5 \mathrm{mg} \mathrm{mL}^{-1}, \mathrm{IC}_{50}=40.09 \mu \mathrm{g} / \mathrm{mL}$, followed by inhibition, $\mathrm{IC}_{50}=400.98 \mu \mathrm{g} / \mathrm{mL}$, of the extract at $1.5 \mathrm{mg} \mathrm{mL}^{-1}$ concentration. The last studied enzyme as XO (Xanthine oxidase) is a flavoprotein, which catalyses the oxidation of hypoxanthine to xanthine and generates superoxide and uric acid. It has been shown that enzyme inhibitors may be useful for the treatment of the common metabolic disorders as hyperuricemia and gout. There are a numerous studies which evaluate the potential of terrestrial plants as XO inhibitors [29-31]. However, this research is the first report on the XOI activity of lichens and provided evidences indicated that the extract is able to exhibit high inhibition on XO activity $\left(\mathrm{IC}_{50}=11.02 \mu \mathrm{g} / \mathrm{mL}\right)$. Purwantiningsih and Purwantini concluded that the inhibition of xanthine oxidase activity of plant extracts is contributed by phenols and anthraquinones compounds and the present phytochemical screening study revealed C. biatorina contains phenols and anthraquinones [32].

Brine shrimp lethality bioassay is an efficient, rapid and inexpensive assay for testing the bioactivity of lichen extracts. It is an excellent choice for elementary toxicity researches based on the ability to kill laboratory-cultured Artemia salina. In the present investigation like previous researchers $[4,33]$, most of the antimicrobial and antioxidant active lichen species are not toxic against Artemia larvae which could be an indication of being non-toxic lichen species. In other words, in the current study, the brine shrimp lethality bioassay is performed to assess the preliminary toxicity of $C$. biatorina. Even though the brine shrimp test does not provide any adequate information regarding the mechanism of action of the lichen extracts it is useful to assess the toxicity and indicates the cytotoxic nature of the lichen and warrant further investigation.

Results of this study showed in vitro pharmacological properties (e.g. enzymes inhibitory, antimicrobial and antioxidant activities) of the extract. Further in vivo experiments are necessary to investigate it.

\subsection{Conclusions}

It was shown that the lichen $C$. biatorina with high anthraquinones (e. g. parietin, rhein, emodin and 1,8-Dihydroxy-3-(hydroxymethyl)-6- methoxy-9.10anthracenedione) content can serve as a good inhibitor of xanthine oxidase (XO), aldehyde oxidase (AO) and $\alpha$-glucosidase enzymes. Also, it revealed the medicinal importance as antimicrobial and antioxidant agent. Whether these effects on enzymes and microorganisms have received much attention from researchers, and it would be of value to perform more studies using animal model for human therapy. Also further work needs to be carried out on the lichen in other to determine the active chemical constituents responsible for the observed activities.

\section{Acknowledgments}

The author acknowledges the hospitality of Dagmar Triebel who allowed her to visit the Botanische Staatssammlung Munchen (M). Also thanks to John Elix (Canberra, Australia) for helping to do HPLC and identify the compounds.

\section{Footnotes}

Authors' Contribution: All design, work, statistical analysis and manuscript writing was done by the author.

Conflict of Interest: The author declares no conflict of interest.

Funding/Support: This study was financially supported by Ilam University.

\section{References}

1. Mohamed Sham Shihabudeen H, Hansi Priscilla D, Thirumurugan K Cinnamon extract inhibits alpha-glucosidase activity and dampens postprandial glucose excursion in diabetic rats. Nutr Metab (Lond) 2011;8(1):46. doi: 10.1186/1743-7075-8-46. [PubMed: 21711570].

2. Bahadori MB, Valizadeh H, Asghari B, Dinparast L, Farimani M, Bahadori S. Chemical composition and antimicrobial, cytotoxicity, antioxidant and enzyme inhibitory activities of Salvia spinosa L. J Function Foods. 2015;18:727-36.

3. Mohamed EA, Siddiqui MJ, Ang LF, Sadikun A, Chan SH, Tan SC, et al. Potent alpha-glucosidase and alpha-amylase inhibitory activities of standardized 50\% ethanolic extracts and sinensetin from Orthosiphon stamineus Benth as anti-diabetic mechanism. BMC Complement Altern Med. 2012;12:176. doi:10.1186/1472-6882-12-176. [PubMed: 23039079].

4. Verma N, Behera BC, Sharma BO. Glucosidase inhibitory and radical scavenging properties of lichen metabolites salazinic acid, sekikaic acid and usnic acid. Hacettepe J Biol Chem. 2012;40(1):7-21.

5. Matsuda H, Nishida N, Yoshikawa M. Antidiabetic principles of natural medicines. V. Aldose reductase inhibitors from Myrcia multiflora DC. (2): Structures of myrciacitrins III, IV, and V. Chem Pharm Bull (Tokyo). 2002;50(3):429-31. [PubMed: 11911215].

6. Garattini E, Terao M. Aldehyde oxidase and its importance in novel drug discovery: present and future challenges. Expert Opin Drug Discov. 2013;8(6):641-54. doi: 10.1517/17460441.2013.788497. [PubMed: 23565746].

7. Sorouraddin MH, Fooladi E, Naseri A, Rashidi MR. Development of a sensitive spectrofluorometric-multivariate calibration method for enzyme kinetic of aldehyde oxidase. Iran J Pharm Res. 2010:169-77.

8. Valadbeigi T, Bahrami AM, Shaddel M. Antibacterial and Antifungal Activities of Different Lichens Extracts. J Med Microbiol Infect Dis. 2014;2(2):71-5. 
9. Culberson CF. Improved conditions and new data for the identification of lichen products by a standardized thin-layer chromatographic method. J Chromatogr. 1972;72(1):113-25. [PubMed: 5072880].

10. Culberson CF, Johnson A. Substitution of methyl tert.-butyl ether for diethyl ether in the standardized thin-layer chromatographic method for lichen products. J Chromatograph A. 1982;238(2):483-7.

11. Orange A, James PW, White FJ. Microchemical methods for the identification of lichens. Twayne Publishers; 2001.

12. Elix J, Giralt M, Wardlaw J. New chloro-depsides from the lichen Dimelaena radiata. Bibl Lichenol. 2003;86:1-7.

13. Allen-Gipson DS, Zimmerman MC, Zhang H, Castellanos G, O'Malley $\mathrm{JK}$, Alvarez-Ramirez $\mathrm{H}$, et al. Smoke extract impairs adenosine wound healing: implications of smoke-generated reactive oxygen species. Am J Respir Cell Mol Biol. 2013;48(5):665-73. doi: 10.1165/rcmb.20110273OC. [PubMed: 23371060].

14. Lesjak MM, Beara IN, Orcic DZ, Petar KN, Simin ND, Emilija SD, et al. Phytochemical composition and antioxidant, anti-inflammatory and antimicrobial activities of Juniperus macrocarpa Sibth. et Sm. J Function Foods. 2014;7:257-68.

15. Talaz O, Gulcin I, Goksu S, Saracoglu N. Antioxidant activity of 5,10-dihydroindeno[1,2-b]indoles containing substituents on dihydroindeno part. Bioorg Med Chem. 2009;17(18):6583-9. doi: 10.1016/j.bmc.2009.07.077. [PubMed:19683932].

16. Ercetin T, Senol FS, Orhan IE, Toker G. Comparative assessment of antioxidant and cholinesterase inhibitory properties of the marigold extracts from Calendula arvensis L. and Calendula officinalis L. Indust Crops Products. 2012;36(1):203-8.

17. Zhao H, Fan W, Dong J, Lu J, Chen J, Shan L, et al. Evaluation of antioxidant activities and total phenolic contents of typical malting barley varieties. Food Chem. 2008;107(1):296-304.

18. Salehi P, Asghari B, Esmaeili MA, Dehghan H, Ghazi I. -Glucosidase and-amylase inhibitory effect and antioxidant activity of ten plant extracts traditionally used in Iran for diabetes. $J$ Med Plants Res. 2013;7(6):257-66.

19. Giancarlo S, Rosa LM, Nadjafi F, Francesco M. Hypoglycaemic activity of two spices extracts: Rhus coriaria L. and Bunium persicum Boiss. Nat Prod Res. 2006;20(9):882-6. doi: 10.1080/14786410500520186. [PubMed: 16753927].

20. Govindappa M, Sadananda TS, Channabasava R, Raghavendra VB. In vitro anti-inflammatory, lipoxygenase, xanthine oxidase and acetycholinesterase inhibitory activity of Tecoma stans (L.) Juss. Ex kunth. Int J Pharm Bio Sci. 2011;2(2):275-85.

21. Marasini BP, Baral P, Aryal P, Ghimire KR, Neupane S, Dahal N, et al. Evaluation of antibacterial activity of some traditionally used medicinal plants against human pathogenic bacteria. Biomed Res Int
2015;2015:265425. doi: 10.1155/2015/265425. [PubMed: 25738151].

22. Nair BR. Brine shrimp lethality assay in two species of biophytum dc.(oxalidaceae). Int J Pharm Pharm Sci. 2014;6(4):582-6.

23. Thadani VM, Khan SN, Karunratne V, Choudhary MI. $\alpha$-Glucosidase inhibitors from lichens United States patent; 2011. Available from: https://www.google.com/patents/US7867989.

24. Rabia R, Zaitoon I, Sajid A, Muhammad N, Muhammad YK, Jamshed I. Identification of highly potent and selective $\alpha$-Glucosidase inhibitors with antiglycation potential, isolated from Rhododendron arboretum. R. Nat Prod. 2015;9:262-6.

25. Karunaratne V, Thadhani VM, Khan SN, Choudhary MI. Potent $\alpha-$ glucosidase inhibitors from the lichen Cladonia species from Sri Lanka. J Nat Sci Found Sri Lanka. 2014;42(1).

26. Yang D, Zhao J, Liu S, Song F, Liu Z. The screening of potential $\alpha$ glucosidase inhibitors from the Polygonum multiflorum extract using ultrafiltration combined with liquid chromatography-tandem mass spectrometry. Analyt Methods. 2014;6(10):3353-9.

27. Arvindekar A, More T, Payghan PV, Laddha K, Ghoshal N, Arvindekar A. Evaluation of anti-diabetic and alpha glucosidase inhibitory action of anthraquinones from Rheum emodi. Food Funct. 2015;6(8):2693-700. doi: 10.1039/c5fo00519a. [PubMed: 26145710].

28. Shivanna R, Parizadeh H, Garampalli RH. Screening of lichen extracts for in vitro antidiabetic activity using alpha amylase inhibitory assay. Int J Biol Pharm Res. 2015;6(5):364-7.

29. Liu X, Chen R, Shang Y, Jiao B, Huang C. Lithospermic acid as a novel xanthine oxidase inhibitor has anti-inflammatory and hypouricemic effects in rats. Chem Biol Interact. 2008;176(2-3):137-42. doi: 10.1016/j.cbi.2008.07.003. [PubMed: 18694741].

30. Wang SY, Yang CW, Liao JW, Zhen WW, Chu FH, Chang ST. Essential oil from leaves of Cinnamomum osmophloeum acts as a xanthine oxidase inhibitor and reduces the serum uric acid levels in oxonate-induced mice. Phytomedicine. 2008;15(11):940-5. doi: 10.1016/j.phymed.2008.06.002. [PubMed: 18693097].

31. Filha ZS, Vitolo IF, Fietto LG, Lombardi JA, Saude-Guimaraes DA Xanthine oxidase inhibitory activity of Lychnophora species from Brazil ("Arnica"). J Ethnopharmacol. 2006;107(1):79-82. doi: 10.1016/j.jep.2006.02.011. [PubMed: 16621372].

32. Purwantiningsih HAR, Purwantini I. Anti-hyperuricemic activity of the kepel (Stelechocarpus burahol (Bl.) Hook. F. \& Th.) leaves extract and xanthine oxidase inhibitory study. Int J Pharm Pharm Sci. 2010;2(2):122-7.

33. Veni T, Pushpanathan T. Comparison of the Artemia salina and Artemia fransiscana bioassays for toxicity of Indian medicinal plants. J Coast Life Med. 2014;2(6):453-7. 